\title{
Sporogenesis and development of gametophytes in an endangered plant, Tetracentron sinense Oliv
}

\author{
Xiaohong Gan, Dan Xie, Lingling Cao \\ College of Life Science, China West Normal University, Nanchong, Sichuan Province 637009, China
}

\begin{abstract}
The sporogenesis and development of gametophytes in Tetracentron sinense Oliv. were studied with light microscopy. The anther has four microsporangia; its primary anther wall consists of an epidermis, an endothecium, one or two middle layers and one glandular tapetum. Simultaneous cytokinesis follows meiosis, forming a tetrahedral tetrad. Mature pollen grains are two-celled at the time of anther dehiscence. Its ovule is anatropous, bitegmic and crassinucellate; the development of the female gametophyte is of the monosporic 8-nucleate Polygonum type. Significantly, some striking features were first found in T. sinense: (1) anther dehiscence occurs soon after the endothecium fibrously thickens and the intersporangial septum degenerates; (2) tapetum degeneration is retarded, persisting up to the stage of two-celled pollen grain; (3) a few cellular events such as the vacuolization and the contraction and deformation of the pollen mother cell (PMC) and microspore are not normal at the PMC, dyad and tetrad stages. The abnormalities during male reproduction might be one of important factors resulting in the poor natural regeneration of T. sinense.
\end{abstract}

Key words: Tetracentron sinense Oliv.; Sporogenesis; Development of gametophytes; Natural regeneration.

\section{INTRODUCTION}

Tetracentron sinense Oliv. is a deciduous tree with catkin-like inflorescences, placed either in its own family, Tetracentraceae (Fu and Bartholomew, 2001), or more commonly in the Trochodendraceae together with the monotypic Trochodendron (Martyn and Peter, 2007). This species is today restricted to central and southern China, northern Vietnam, northern Burma, and south of the Himalayas to eastern Nepal, Bhutan and northeastern India (Fu and Bartholomew, 2001), and mainly scattered within a region $24^{\circ}-34.5^{\circ} \mathrm{N}, 98^{\circ}-111.5^{\circ} \mathrm{E}$ and $900-3500 \mathrm{~m}$ above sea level, where the annual average temperature is about $11^{\circ} \mathrm{C}$, the annual rainfall is about 1200 $\mathrm{mm}$, and the relative humidity about 85\% (Zhang, 1999). Flowering occurs from April to July and fruiting from July to October (Fu and Bartholomew, 2001). Due to its rarity and poor ability to regenerate naturally, it has been listed as a national second-grade protected plant species in China (Fu, 1992).

$T$. sinense has been used for furniture by local people for many centuries, and also used as an ornamental plant for forestation as well as a medicinal plant (Luo, 1998; Wang et al., 2006; Lai et al., 2010). As its vessel-free wood is quite rare in angiosperms, suggesting primitiveness, the species has received much taxonomic attention (Ren et al. 2007). So far, there are comprehensive studies on its morphology, anatomy, floral organogenesis (Chen et al., 2007; Ren et al. 2007), palynology (Zhang et al., 1999), phytochemistry (Wu et al., 2000; Zheng et al., 2000; Yi et al., 2000; Lai et al., 2010) and systematics (APG, 2009). Previous studies have mainly focused on discussing its systematic status. Recently, a few investigations on seed germination and seedling initial growth have been reported ( $\mathrm{Xu}$ et al., 2006; Zhou, 2007; Gan et al., 2008; Luo et al., 2010).

Plant natural regeneration is correlated with the sexual reproduction process, through which a plant can maintain its genetic diversity for adapting to the external environment. Knowledge of reproductive biology is necessary for effective protection of endangered plants. It has been reported that abnormalities during plant sexual reproduction, such as abnormal development of sporogenesis and loss of the pollination vector (Pan et al., 2001, 2003; Xue et al., 2005; Xiao and $\mathrm{Xu}, 2006$; Zhao et al., 2008) can influence the effectiveness of reproduction, resulting in poor natural regeneration. To date, little is known about sporogenesis and gametogenesis in $T$. sinense or the impact of abnormalities during these processes on natural regeneration.

In this study, sporogenesis and development of gametophytes in Tetracentron sinense were studied with light microscopy. The objective of this study was to deepen the understanding of the reproductive biology of $T$. sinense and to discuss its influence on natural regeneration, as well as to provide important information for the conservation of this endangered species.

\section{MATERIALS AND METHODS}

\section{Plant meterials}

Plant material of Tetracentron sinense was collected for the reproductive biology study from a natural population in the Emei Mountain Natural Reserve (Sichuan, China). The vouchers (Gan Xiaohong 200700A) were deposited in the Herbarium of China West Normal University (CWNU).

\section{Cytological studies}

The inflorescences of a range of developmental stages were collected from 2007 to 2009. For light microscopy, the developing inflorescences were dissected and fixed for 1 $\mathrm{h}$ in Carnoy's fixative solution $(100 \%$ ethanol and acetic 
acid, $1: 1 \mathrm{v} / \mathrm{v}$ ), and then stored in $70 \%$ ethanol at $4{ }^{\circ} \mathrm{C}$. After being stained with Ehrlich's hematoxylin; specimens were embedded in paraffin and the blocks were sectioned at 6-8 $\mu \mathrm{m}$ with a Leica 2126 microtome (Germany). Observations and photography were carried out using a Motic BA300 microscope.

\section{RESULTS}

Microsporogenesis and male gametophyte formation

The anther has four sporangia (Fig.1, A), and each has a row of archesporia differentiated just beneath the epidermis. The archesporial stage of microsporogenesis was first observed in buds collected in mid March. Microsporogenesis and male gametophyte development take place from mid March to early August.

\section{Formation of anther wall}

In mid March, the primary anther wall was observed to be composed of four to five cell-layers: from the outer to the inner layer, one single layer of epidermis, one row of endothecium, one to two rows of middle layers and one row of mononucleate tapetal cells (Fig.1, B). At the beginning of pollen mother cell (PMC) meiosis the tapetal cells are binucleate (Fig.1, C), and then become vacuolated (Fig.1, D) and degenerate in situ gradually (Fig.1, A, E-F). Thus the tapetum is of glandular type. With the development of the tapetal cells, the endothecial cells expand gradually and become vacuolated (Fig.1, D). After undergoing U-shaped thickening (Fig.1, F), the endothecium develops into a fibrous layer (Fig.1, G). All middle layers are ephemeral (Fig.1, D) and disintegrate (Fig.1, E) quickly, while the endothecium develops fibrous thickening. Thus the mature anther wall contains two cell layers; the epidermis and the fibrous layer (Fig.1, G-H)

At the time of middle layer disintegration, some subepidermal cells between the two locules of each theca become specialized to form the intersporangial septum, and a small set of specialized epidermal cells develop into the stomium (Fig.1, E). Afterward, degeneration of the intersporangial septum occurs first (Fig.1, G) uniting the two locules of each theca into a confluent chamber (Fig.1, H). Following this stage, the stomium splits. As a result of the process, the anther wall dehisces by two longitudinal slits and the pollen grains are released from the anther (Fig.1, I).
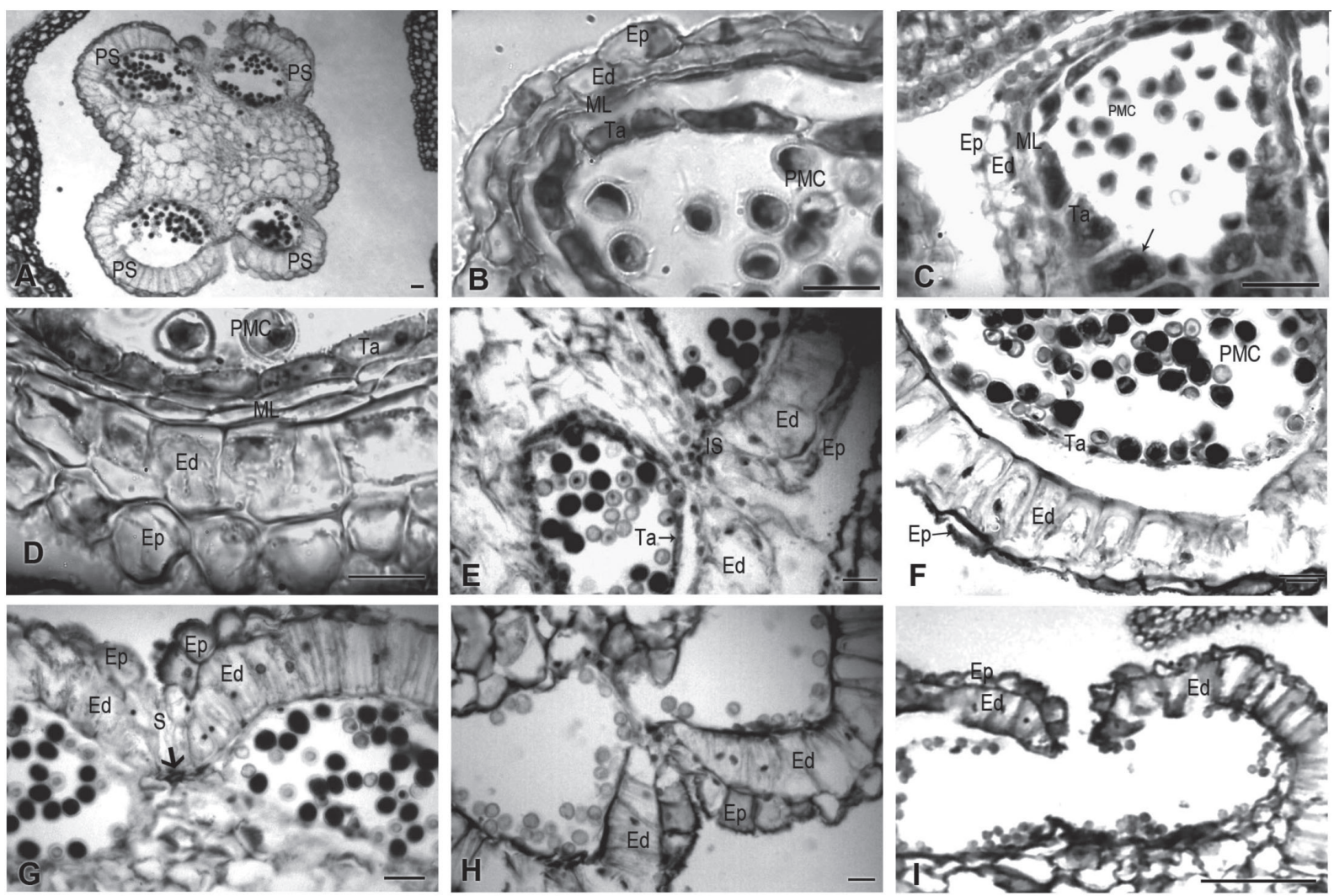

Fig. 1 The development of anther wall in Tetracentron sinense.

A. The anther of each stamen has four sporangia; B. At the PMC stage, the primary anther wall is composed of an epidermis, an endothecium, one or two middle layers and a tapetum; $C$. The tapetal cells are binucleate; $D$. The endothecium expands its volume and is vacuolated, and two middle layers are flattened; E. The formation of intersporangial septum and stomium, and the degeneration of middle layers; F. The U-shape thickening of endothecium and the degeneration of tapetal cells; $\mathrm{G}$. The fibrous layer and the degeneration of intersporangial septum (arrow); $\mathrm{H}$. The two locules of each theca were united to a confluent chamber after the degeneration of the intersporangial septum; I. Anther dehiscence after the splitting of the stomium.

Scale bar $=10 \mu \mathrm{m}$. Ed: endothecium; Ep: epidermis; IS: intersporangial septum; ML: middle layer; PS: pollen sac; PMC: pollen mother cell; S: stomium; Ta: tapetum. 


\section{Microsporogenesis and male gametophyte formation}

In early April, a row of sporogenous cells deriving from archesporial cells give rise to a mass of PMCs (Fig.2, A). The PMC undergoes one meiotic division, contributing to form a tetrahedral tetrad (Fig.2, B-E). The cytokinesis of microspores follows the simultaneous type. Cell plate is not laid down after meiosis I (Fig.2, B-C), but simultaneously comes into being after meiosis II (Fig.2, E). In early July, the microspores separate from each other and individually develop into pollen grains with dense cytoplasm and a central nucleus (Fig.2, F). Afterward, the microspore cytoplasm gradually becomes sparse and vacuolated, and the nucleus takes a peripheral position when its tricolpate apertures form (Fig.2, G). In mid July the microspore nucleus proceeds into mitosis, resulting in the formation of two unequal cells, a large vegetative one and a smaller generative one. The generative cell becomes spindleshaped and is enclosed in the vegetative cell (Fig.2, H). As development proceeds into early August, the generative cell is integrated into the vegetative one, indicating the formation of mature pollen. At the time of anther dehiscence, the pollen grains are 2-celled.

Significantly, a few abnormalities were investigated during microsporogenesis and male gametophyte development. At the

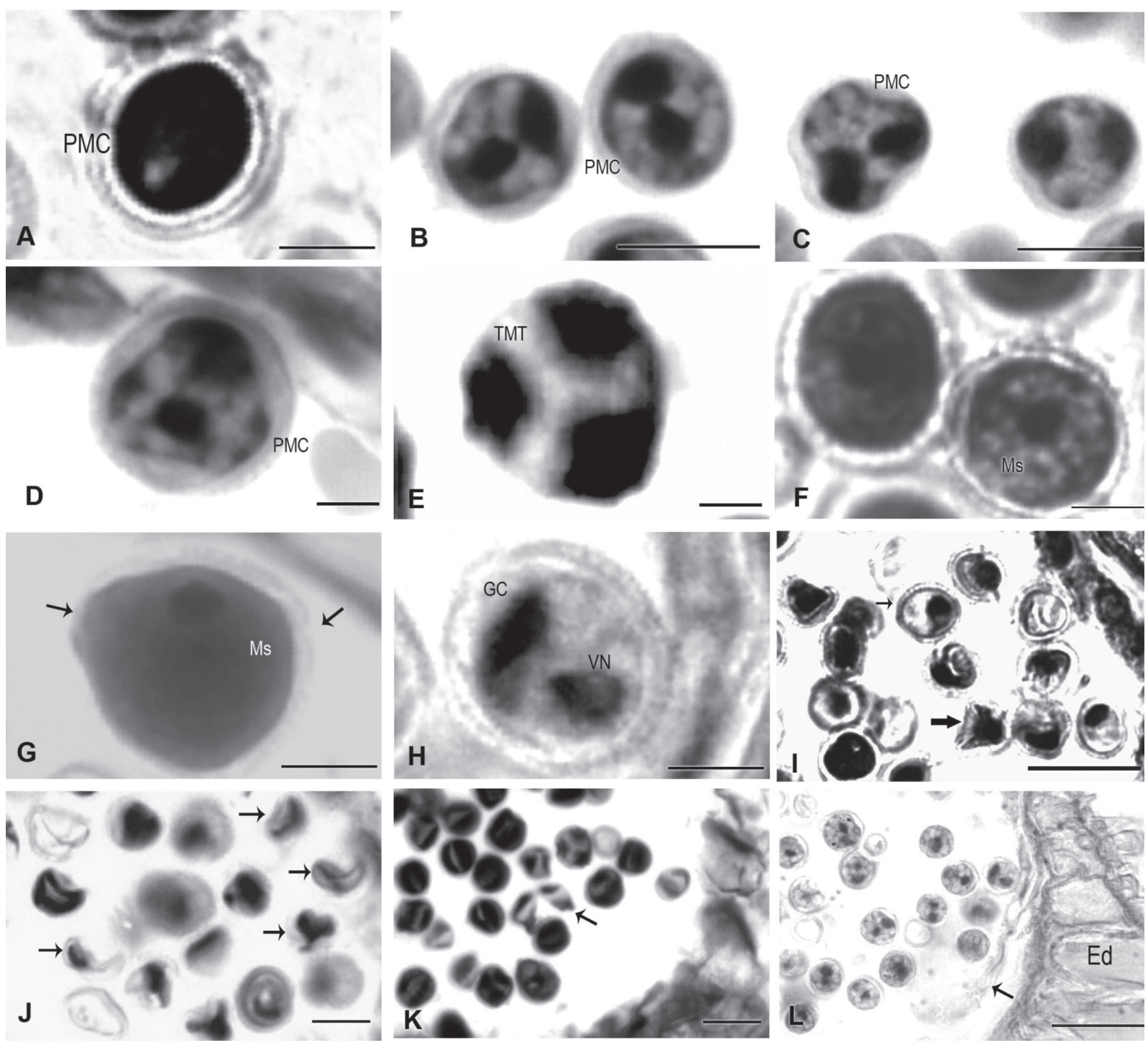

Fig. 2 Microsporogenesis and abnormal development during the process.

A. The microspore mother cell; B. Two daughter nuclei may be observed in a PMC, showing telophase I of PMC meiosis; C. The PMC was tetrahedral and only two daughter nuclei in a PMC, showing prophase II of PMC meiosis; D. Four daughter nuclei can be observed in a PMC, but the cell plate was not investigated, showing telophase II of PMC meiosis; E. The tetrahedral tetrad of microspores; F. Newly released uninucleate microspores; G. The uninucleate microspore with apertures (arrow); H. Two-celled pollen with generative cell and vegetative cell; I. The PMC stage, showing the vacuolated PMC with adhesion of nucleus and cytoplasm (small arrow), and the shrinkage PMC (large arrow); J. The meiosis I stage of PMC, showing the shrinkage PMC (arrow); K. The tetrad stage, showing the PMC contracted and bony (arrow); L. The two-celled pollen stage, showing the persistent tapetum (arrow).

Scale bars $=50 \mu \mathrm{m}$ in figures $\mathrm{A}, \mathrm{E}-\mathrm{H} ; 10 \mu \mathrm{m}$ in figures B-D, I-L. Ed: endothecium; GC: generative cell; Ms: microspore; PMC: pollen mother cell; TMT: tetrahedral tetrad; VN: vegetative cell nucleus. 
PMC stage, PMCs partly become vacuolated, and their nuclei are adhesive with their cytoplasm (Fig.2, A). The contraction and deformation of PMCs was observed at the stage of PMC (Fig.2, I), dyad (Fig.2, J) and tetrad (Fig.2, K). Especially, over 50\% PMCs contract seriously to become bony at the tetrahedral tetrad stage (Fig.2, L). The tapetum of the anther wall degenerates in situ slowly, and is persistent at the stage of two-celled pollen grain (Figure 21).

Megasporogenesis and female gametophyte formation

In early April, a parenchyma cell beneath the epidermis of the ovule in the micropyle end develops into an archesporial cell, characterized by dense cytoplasm and large nucleus (Fig.3, A). Afterwards, the archesporial cell divides periclinally into two cells, the parietal cell and the sporogenous cell (Fig.3, B). In mid June, the parietal cell undergoes several periclinal and anticlinal divisions to form nucellus cells, and the sporogenous cell develops directly into the megaspore mother cell (MMC), recognized by dense cytoplasm and large nucleus (Fig.3, C). The functional MMC becomes deeply embedded in the tissue of the nucellus, hence the type of ovule is crassinucellate. At the same time, inner and outer integument with 2-layer cells are well defined (Figure 24), and then the ovule becomes gradually anatropous (Fig.3, D).

After undergoing successive changes during meiosis, the MMC divides into two equal dyad cells (Fig.3, E) and then the linear tetrad forms. After this the chalazal cell functions as a megaspore, but the other three cells gradually degenerate (Fig.3, F). Finally, the functioning megaspore

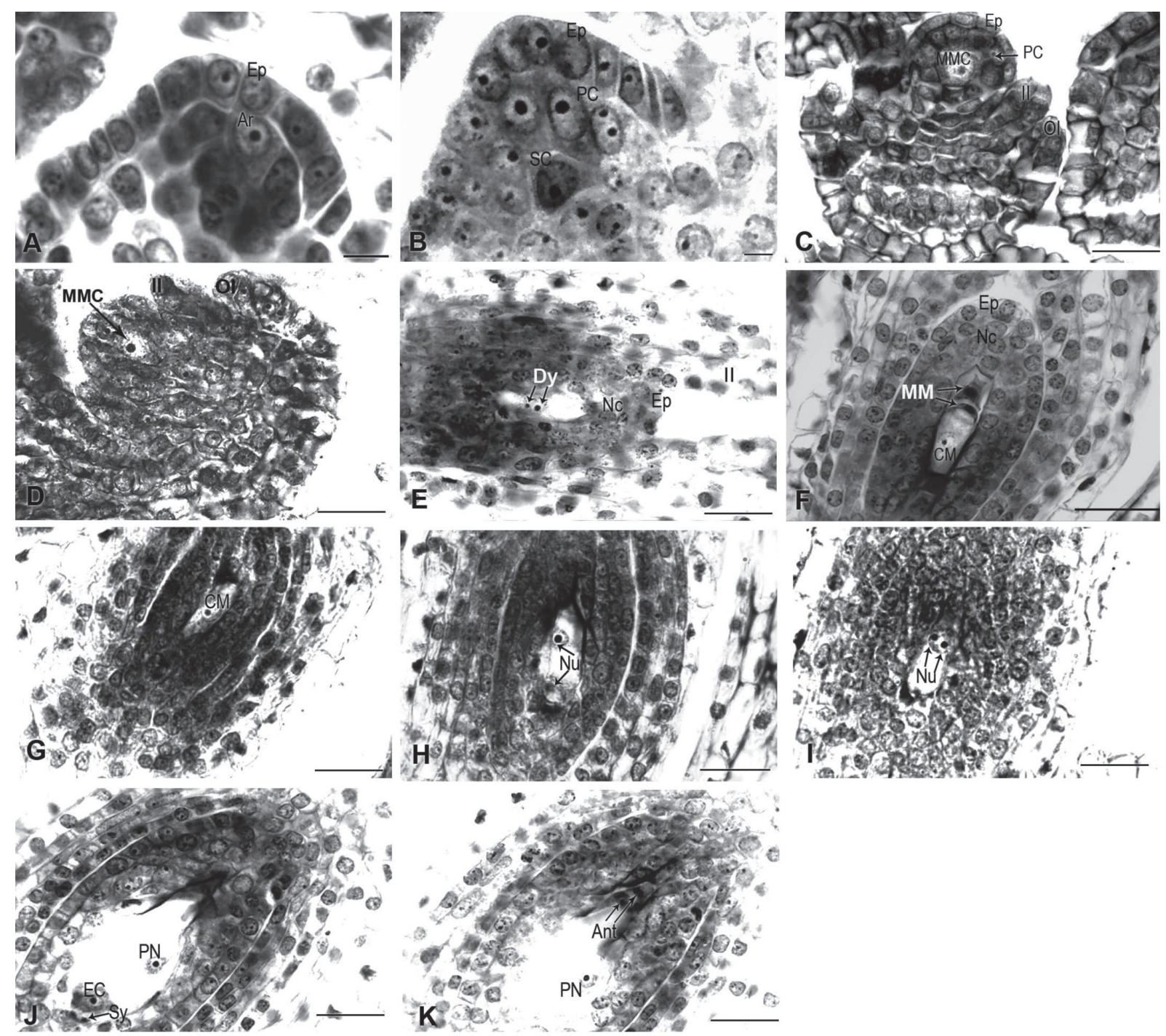

Fig. 3 Megasporogenesis and the development of the female gametophyte.

A. The archesporium of the female gametophyte; B. The parietal cell and sporophyte cell; C. Megaspore mother cell and the formation of inner and outer integument; D. The anatropous ovule; E. Dyad; F. The functional megaspore with the degenerating megaspores; G. Uninucleate embryo sac; $\mathrm{H}$. Binucleate embryo sac; I. Two nuclei from the four nucleate gametophyte are visible in a transverse plane; J-K. Consecutive sections, showing the mature 8-nucleate embryo sac.

Scale bars $=10 \mu \mathrm{m}$. ANT: antipodal cell; Ar: archesporium; CM: chalazal megaspore; Dy: dyad; EC: egg cell; Ep: epidermis; II: inner integument; MM: micropylar megaspore; MMC: megaspore mother cell; Nc: nucellus; Nu: nucleus; OI: outer integument; PC: parietal cell; PN: polar nucleus SC: sporophyte cell; Sy: synergid. 
becomes incrassate and vacuolated, and the nucleus is suspended in the center (Fig.3, G), indicating the completion of megasporogenesis.

In early July, the uni-nucleate female gametophyte coming directly from the functional megaspore increases its volume, then produces two daughter nuclei which move apart to the two poles of the female gametophyte (Fig.3, H). After three mitotic divisions, the megaspore develops into an eightnucleate female gametophyte (Fig.3, I-K). The development of the female gametophyte thus conforms to the monosporic 8-nucleate Polygonum type. As nuclear division proceeds the female gametophyte enlarges its volume prominently, and three nuclei at the micropylar end constitute the egg apparatus, consisting of an egg cell and two synergids, and the three cells at the chalazal end become the antipodals (Fig.3, J-K). Simultaneously, one nucleus migrates to the middle of the female gametophyte from the micropylar or chalazal pole, leading to the formation of polar nuclei (Fig.3, J-K).

\section{DISCUSSION}

In this study, the sporogenesis and development of gametophytes in $T$. sinense were analyzed in order to reveal the factors affecting natural regeneration. The reproductive biology features of $T$. sinense may be summarized as follows. The anther of each stamen is of four sporangia. The anther wall prior to maturation consists of an epidermis, an endothecium, one or two middle layers and one glandular tapetum. Simultaneous cytokinensis follows meiosis to produce tetrahedral tetrads. The mature pollens are two-celled at the time of anther dehiscence. The ovule is anatropous, bitegmic and crassinucellate, and the development of the female gametophyte is of the monosporic 8-nucleate Polygonum type. The results presented are in agreement with the previous report. Significantly, some striking features were first found in T. sinense: (1) anther dehiscence occurs soon after the endothecium fibrously thickens and the intersporangial septum degenerates; (2) tapetum degeneration is retarded, persisting up to the stage of two-celled pollen grain; (3) a few cellular events such as the vacuolization and the contraction and deformation of PMC and microspore are not normal at the stage of PMC, dyad and tetrad.

Anther dehiscence is the terminal step in anther development that causes the release of pollen grains from the anther (Scott et al., 2004). As poor dehiscence of anthers causes a decreased yield of seed and influences the reproduction of plants (Matsui et al., 1999), the anther dehiscence mechanism has received considerable attention. Hitherto, the anther dehiscence mechanisms in angiosperms are of four basic types. (1) In most angiosperms, the expansion and fibrous thickening of the endothecium and the splitting of the stomium are required for anther dehiscence. (2) In tobacco and other solanaceous plants, two specialized cell types, the stomium and the circular cell, cluster within the notch region and are associated with anther dehiscence (Beals and Goldberg, 1997). (3) In most non-solanaceous plants (D'Arcy, 1996; Sanders et al., 2005), specialized septum cells in the notch region of these anthers function analogously in dehiscence. (4) In rice, the U-shaped thickening in the endothecium wall and the rupture of the septum and splitting of the stomium contribute to anther dehiscence (Matsui et al., 1999). Interestingly in T. sinense, the endothecial layer fibrously thickens after the
U-shaped thickening, and then the intersporangial septum degenerates and the stomium splits, leading to anther dehiscence. The result suggests that the anther dehiscence of $T$. sinense should be attributed to a synergetic effect between the fibrous thickening of endothecium and the degeneration of the intersporangial septum and stomium, which is in disagreement with previous reports (Beals and Goldberg, 1997; Matsui et al., 1999; Sanders et al., 2005). Further studies on the cytological and cytochemical dynamics of the endothecium and intersporangial septum during development in this species will probably reveal the mechanism of anther dehiscence.

There are a few reports about abnormal development of the PMC during microsporogenesis, such as the vacuolization and contraction of $\mathrm{PMC}$, and the adhesive phenomenon of PMC and pollen (Pan et al., 2001, 2003; Wang et al., 2005; Zhao et al., 2008). In general, the abnormalities during PMC development usually correlated with pollen abortion, affecting the efficiency of reproduction (Zhao et al., 2008). Additionally, a persistent tapetum was usually present in some male sterile plants (Gorman and McCormick, 1997; Chaubal et al., 2000), and the retarding of its degeneration can block the nutrient transportation which is necessary for the microspores to develop into viable pollen grains (Buyukkartal et al., 2005). In the present study, the abnormal development of the microspore and tapetum during male reproduction of $T$. sinense would result in pollen abortion and affect the efficiency of sexual reproduction and thus affect seed set, which might be one of the important factors resulting in the poor natural regeneration of this species. To date, little is known about the cause of the abnormalities during sporoand gametogenesis of $T$. sinense. To conserve effectively this medicinal plant and accelerate the development of medicine in China, further research should be carried out to reveal the reason for the abnormal development of the microspore and taptum during male reproduction in $\mathrm{T}$. sinense.

\section{ACKNOWLEDGEMENTS}

This work was supported by the youth fund of natural science of education department, Sichuan Province, China (No. 06B038) and the National Natural Science Fund of China (No. 30271064).

\section{REFERENCES}

ANGIOSPERM PHYLOGENY GROUP (2009). An update of the angiosperm phylogeny group classification for the orders and families of flowering plants: APG III. Bot. J. Linn. Soc. 161: 105-121.

BEALS TP, GOLDBERG RB (1997). A novel cell ablation strategy blocks tobacco anther dehiscence. Plant Cell 9: 1527-1545.

BUYUKKARTAL HN, ÇOLGECEN H, MARASALI B (2005). Development of anther wall throughout microsporogenesis in Vitis vinifera L. Cv. Çavuş. Int. J. Agri. Bio. 7:616-620

CHAUBAL R, ZANELLA C, TRIMNELL MR, et al. (2000). Two male-sterile mutants of Zea mays (Poaceae) with an extra cell division in the anter wall. Amer. J. Bot. 87:1193-2010.

CHEN L, REN Y, ENDRESS PK, et al.(2007). Floral organogenesis in Tetracentron sinense (Trochodendraceae) and its systematic significance. Plant Syst. Evol. 264: 183-193.

D'ARCY WG (1996). Anthers and stamens and what they do. In: D'Arcy WG, Keating RC (eds) The anther: form, function and phylogeny. Cambridge: Cambridge University Press, pp 1-24

FU DZ, BARTHOLOMEW BRUCE (2001). Tetracentron in Wu ZY and Raven P H. Flora of China, 6: 125. Science Press, Beijing and Missouri Botanical Garden Press.

FU LG (1992). Plant red book in China-rare and endangered plants (Book I). China Science Press, Beijing, pp 452-453, 682-683. 
GAN XH, TIAN MJ, LUO YJ (2008). Study on the characteristics of seed germination of endangered plant Tetracentron sinense. J. China West Norm. Uni. (Nat. Sci.) 29(2): 132-135.

GORMAN SW, MCCORMIC S (1997). Male sterility in tomato. Critical Rev. in Plant Sci. 16: 31-53.

KARACHI1 M, GIATHI G, MUCHIRI NM (2006). Factors influencing the natural regeneration of Polyscias kikuyensis Summerh in Nyamweru forest - Kikuyu escarpment, Kenya. Afr. J. Ecol. 45, 242-248.

LAI GF, WANG XY, CAO JX, et al. (2010). Extraction and separation of the chemical constituents in Tetracentron sinense. J. Henan Univ. ( Nat. Sci.) 40(2):141-146.

LUO JD, GAN XH, JIA XJ, et al. (2010). Biological characteristic of Seeds of Endangered Plant Tetracentron sinense (Tetracentraceae). Acta Bot. Yunnan. 32 (3) : 204-210.

LUO SD (1998). The study of anti HIVactivity of Traditional Chinese Medicine. Yunnan science and technology Press, Kunming, pp 63.

MARTYN R, PETER C (2007). Tetracentron sinense. The Board of Trustees of the Royal Botanic Gardens, Kew, 168-173.

MATSUI T, OMASA K, HORIE T (1999). Mechanism of anther dehiscence in rice (Oryza sativa L.). Ann.Bot. 84: 501-506.

PAN YZ, GONG X, LIANG HX (2001). Studies on the formation of microspore and development of male gametes in Manglietia insignis. Acta Bot. Yunnan. 23 (1) : 85-90

PAN YZ, LIANG HX, GONG X (2003). Studies on the reproductive biology and endangerment mechanism of the endangered plant Manglietia aromatica. Acta Bot. Sin. 45(3):311-316.

REN Y, CHEN L, TIAN XH, et al. (2007). Discovery of vessels in Tetracentron (Trochodendraceae) and its systematic significance. Pl. Sys Evol. 267: 155-161.

SANDERS PM, BUI AQ, LE BH (2005). Differentiation and degeneration of cells that play a major role in tobacco anther dehiscence. Sex. Plant Reprod. 17: 219-241.

SCOTT RJ, SPIELMAN M, DICKINSON HJ (2004). Stamen structure and function. Plant Cell 16 [Suppl]: 546-560.

SMITH AC (1945). A taxonomic review of Tetracentron and Trochodendron. J. Arnold Arbor. 26: 1231-142.
WANG FX, QIAN NF, ZHANG YL (1984). Observation on pollen morphology of Tetracentron, Trochodendron and Drimys. Acta Phytotax. Sin. 22(6):456-459.

WANG YF, LAI GF, EFFERTH T, et al. (2006). New glycosides from Tetracentron sinense and their cytotoxic activity. Chemistry Biodiv. 3(9) : 1023-1030.

WU XL, ZHOU RH, DUAN JA, et al.(2000). Chemical constituents from the bark of Tetracentron sinensis Oliv. and Trochodendron aralioides Sieb et Zucc. J. Pl. Res. Env. 9(3): 51-57.

XIAO DX, XU FX (2006). Megasporogenesis and development of female gametophyte in Manglietia decidua (Magnoliaceae). Ann. Bot. Fenn. 43:437-444.

XU L, XIONG CY, LI CH (2006). Study on germination characteristic of Tetracentron sinense seed under different osmotic conditions. Seed 25(11): 331-35.

XUE CY, WANG H, LI DZ (2005). Microsporogenesis and male gametogenesis in Musella, a monotypic genus from Yunnan, china. Ann. Bot. Fenn. 42:461-467.

YI JH, ZHANG GL, LI BG, et al. (2000). Two glycosides from the stem bark of Tetracentron sinense. Phytochemistry 53: 1001-1003.

ZHANG P (1999). Study of geographical distribution and biological properties of ecology on Tetracentron sinense. Yantai Teachers Univ. J. (Nat. Sci.) 15(2): 148-150

ZHANG P, FU ZJ, WANG D (1999). Study on micromorphology of pollen and seed coat in Tetracentron sinense Oliv. Yantai Teachers Univ. J. (Nat. Sci.) 15(3): 217-220.

ZHAO XF, SUN WB, YANG HB, et al. (2008). Mega-and microsporogenesis and development of female and male gametophytes of Michelia coriacea (Magnoliaceae), a globally critical endangered plant in southeast Yunnan of China. Acta Bot. Yunn. 30(5): 549-556.

ZHENG XW, ZHANG CK, ZHENG OA, et al. (2000). Studies on the chemical constituents of the bark of Tetracentron sinense. J.Wuhan Bot. Res.18: 536538.

ZHOU YX (2007). Light requirement characteristics for the germination of Tetracentron sinense Oliv. Seeds. J. Central South Univ. For. Technol.27(5): 54-57. 